MONIKA STASIAK

Uniwersytet Ludowy

Rzemiosła Artystycznego

\title{
ŻABKI, LUDZIE I ŚWIAT ZNACZEŃ - PROBLEMY WOKó́ zRóWNOWAżonego ROZWOJU W POLSCE
}

6 anim przejdę do tego, co sprawia mi w pisaniu największa radość - do radości z twórczego i nieskrępowanego (przynajmniej w początkowej fazie) przelewania słów na papier, muszę poczynić na potrzeby tego artykułu pewne założenia, które nieco usprawiedliwią mnie w oczach czytelnika. Tekst nie rości sobie prawa do bycia raportem z badań terenowych ani spisem rekomendacji dla wszystkich, którzy decydują o kształcie ochrony środowiska w Polsce. Wprawdzie znajdują się w nim elementy zarówno jednego jak i drugiego, jednakże połączone zostały chociażby z przykładami antropologii zaangażowanej czy z osobistymi refleksjami i intuicjami autorki, tworząc całość balansującą na pograniczu nauki i literatury. Mam jednak nadzieję, że w odczuciu odbiorców, połączenie takie niczego tekstowi nie ujmie, a może nawet i przyda.

Jak słusznie zauważyła przywoływana przez Clifforda Geertza, Susan Langer, nauka podobnie jak wszystkie inne dziedziny ludzkiej wytwórczości (w tym wypadku intelektualnej), ulega modom na nowe trendy myślowe oraz

idee, które zaznaczają swą obecność w pejzażu intelektualnym z wyjątkowo potężną siłą. Za ich pomocą od razu udaje się rozwiązać tak wiele fundamentalnych problemów, że wydaje się wręcz, iż są one w stanie stać się kluczem do rozwiązania wszelkich problemów tej wagi ${ }^{1}$.

${ }^{1}$ C. Geertz, Opis gęsty: w poszukiwaniu interpretatywnej teorii kultury, [w:] Interpretacja kultur. Wybrane eseje, tłum. M. Piechaczek, Wydawnictwo UJ, Kraków 2005, s. 17. 
Pewne pojęcia powstają $\mathrm{w}$ łonie nauki, zyskują na popularności, a z czasem, pod wpływem permanentnego kryzysu tożsamości albo zwykłego zmęczenia materiału, zużywają się, ustępując miejsca nowym. Kiedy zaś owe pojęcia okazują się być wyjątkowo „chwytliwe”, w płynny sposób stają się udziałem kultury popularnej i zaczynają pomieszkiwać już nie tylko w salach wykładowych, ale też w salonach politycznych, na stronach opiniotwórczych tygodników, w tabelkach unijnych projektów. Niewątpliwie, jednym z takich pojęć jest właśnie zrównoważony rozwój, który mój kolega - aktywista określił swego czasu jako najbardziej wytarty termin z zakresu ochrony przyrody². „Zużycie” pojęcia odnosi się z jednej strony do wykorzystywania go we wszystkich możliwych kontekstach, formach i odmianach, przez wszelkie możliwe instytucje, począwszy od Parlamentu Europejskiego, a skończywszy na telewizji regionalnej i szkołach podstawowych; z drugiej zaś - do ogromnej przepaści pomiędzy jego teoretycznymi ramami, a znacznie mniej wzniosłą praktyką jego funkcjonowania w systemie społeczno-gospodarczym. Jeśli idzie o teorię właśnie, to model ten, jak pisze Teresa Adamska, „zakłada równowagę pięciu rodzajów ładu jako warunek synergicznego rozwoju wszystkich sfer razem i każdej z osobna"3, przy czym do owych sfer zalicza się: środowisko naturalne, gospodarkę, ład przestrzenny, społeczeństwo, oraz politykę i administrację. Mamy tu zatem do czynienia z podejściem holistycznym, w myśl którego całość układu nie może się rozwijać prawidłowo, jeśli pojedyncze jego elementy znajdują się w regresie. Nawet najprężniej rozwijająca się według tych założeń sfera gospodarki, bez uwzględnienia społeczeństwa czy środowiska naturalnego, staje się układem zamkniętym, który zaczyna wpływać destrukcyjnie na wszystkie pozostałe. $Z$ drugiej zaś strony mamy dodającą znacznie mniej otuchy sferę praxis i ową, nawiązującą w pewnym stopniu do wcześniejszych uwag Geertza, prawidłowość - jeśli znaczenie terminu robi się zbyt szerokie, on sam staje się semantycznie pusty. Można by uzupełnić tę refleksję, może nieco ad hoc ukute, prawo antyglobalistów: jeśli jakiś termin z zakresu ochrony przyrody czy środowiska, zaczyna być używany

\footnotetext{
2 No dobrze, może nie do końca posłużył się terminem „wytarty”, jednak dosłowne przytoczenie jego wypowiedzi, zdecydowanie nie powinno pojawić się w akademickim kontekście.

${ }^{3}$ T. Adamska, Analiza kosztów i korzyści związanych z wydobyciem gazu łupkowego, [w:] Obywatele kontroluja, pod red. D. Żuchowskiego, Instytut Spraw Obywatelskich, Łódź 2013, s. 109.
} 
przez firmy i osoby, które z powyższymi nie mają nic wspólnego ${ }^{4}$, oznacza to jego śmierć.

Spróbujmy jednak chwilowo porzucić nieprzystawalność formy i materii, by uwzględnić jeszcze jeden wymiar pojęcia zrównoważony rozwój. Jeśli mianowicie, składać miałaby się nań, prócz innych, również sfera społeczna, wówczas musielibyśmy wziąć pod uwagę nie tylko „twarde” statystyczne dane i wskaźniki, ale również „miękką” siatkę społecznego świata znaczeń. „Myśl ludzka jest domeną absolutnie społeczną: społeczne są jej źródła, funkcje, formy i zastosowania"5 - wskazuje Geertz, zwracając naszą uwagę na to, że znaczenia, które nadajemy swojemu doświadczeniu, nigdy nie są indywidualną własnością każdego z nas, ale zostają przekute na społeczną praxis, stając się tworem intersubiektywnie realnym. Oznacza to, że analiza społecznego wpływu działań dotyczących środowiska naturalnego, pozostaje niepełna, jeżeli uwzględnimy w niej tylko takie parametry jak, ilościowo zbadane: stopa bezrobocia, zarobki czy sympatie wyborcze, a nie skupimy się wcale na niewyrażanych explicite znaczeniach, które ludzie nadają swemu doświadczeniu.

Wspominam zaś o tym nie bez kozery, bowiem praktyka ochrony środowiska pozostaje zgoła odmienna od tych założeń. Naniesienia działań - czy to inwestycyjnych, czy ochronnych - na społeczną siatkę znaczeń, unikają zarówno przedsiębiorcy i organy kontrolne, jak też organizacje ekologiczne. Raporty oddziaływania na środowisko ${ }^{6}$ zawierają jako jeden z obowiązkowych elementów rozdział poświęcony wpływowi danej inwestycji na lokalną społeczność. No dobrze, może „rozdział” to zbyt duże słowo, jeśli wziąć pod uwagę, że zazwyczaj fragment ten kwitowany jest krótkim: „Nie przewiduje się konfliktów z lokalną społecznością”. Gdy zaś sprawa jest na tyle poważna, że nie sposób to pominąć, pojawia się komunikat, dający się odczytać jako:

${ }^{4}$ Praktyka, o której mówię, nosi fachowo miano greenwashingu i polega na wykorzystywaniu pozorów działalności społecznej, ekologicznej itp. przez firmy wyłącznie na potrzeby poprawienia własnego wizerunku, nadwerężonego przez praktykę zgoła odmienną od deklarowanej. Wprawdzie na temat greenwashingu powiedziano już wiele gdzie indziej, jednak autorka, korzystając z przestrzeni wydawniczej, nie pomija również i tej okazji, by uwrażliwić nań czytelnika.

${ }^{5}$ C. Geertz, Osoba, czas i zachowanie na Bali, [w:] Interpretacja kultur. Wybrane eseje, tłum. M. Piechaczek, Wydawnictwo UJ, Kraków 2005, s. 405.

${ }^{6}$ Raporty takie stanowią integralną część oceny oddziaływania na środowisko (OOŚ). Jest ona standardowo przeprowadzana dla wszystkich tych inwestycji, które mogą w sposób znaczący oddziaływać negatywnie na środowisko naturalne, jak również dla wszystkich inwestycji zlokalizowanych na terenach Natura 2000. 
lokalna społeczność to grupa niedouczonych ignorantów, ale jeśli poinformować ją należycie o korzyściach płynących z naszego przedsięwzięcia, natychmiast zmieni zdanie ${ }^{7}$. Żadnych prób analizy, żadnego zrozumienia. Twarde dane inwestora versus przedsądy i zabobony (zapewne niepiśmiennych) wieśniaków. Do tego dodać należałoby jeszcze proces konsultacji społecznych, przeprowadzany w myśl zasady: przedsiębiorca (ewentualnie urzędnik) mówi, obywatel słucha - w końcu konsultować powinno się wyłącznie pozytywnie. Kto zaś nie rozumie, spotkać się może z taką mniej więcej reakcją, jak ta przytaczana przez mojego znajomego - aktywistę społecznego: pan projektant pokazuje mieszkańcom, którędy docelowo będzie biegła planowana droga. „Ale tu stoi moja stodoła!” - protestuje ktoś z uczestników spotkania, na co projektant dokonuje skreślenia rzeczonego budynku z mapy, podsumowując to krótkim „Już nie stoi”. I choć ten przypadek traktować możemy jako pewną skrajność, to założenie, które legło u jego podstaw, jest charakterystyczne dla większości procesów środowiskowych (czy w ogóle decyzyjnych) w naszym kraju: ludzi można traktować tak jak każdą inną zmienną w równaniu zamierzonym na skuteczność podejmowanych działań. Założenie to stanowi po części spuściznę nowoczesnej inżynierii społecznej ${ }^{8}$, po części zaś efekt stłumienia mechanizmów społeczeństwa obywatelskiego w poprzednim ustroju społeczno-politycznym. Skutek jest taki, że nawet na poziomie organizacji z tzw. trzeciego sektora, nie zawsze pojawiają się próby zrozumienia „współczynnika humanistycznego”, którego wartość ustępuje miejsca potrzebie skuteczności prowadzonych działań. Inny z zaprzyjaźnionych aktywistów ${ }^{9}$ określa taką postawę jako

${ }^{7}$ Aby nie być gołosłowną, pozwalam sobie przytoczyć fragment raportu dla poznańskiej spalarni śmieci [podkreślenie M.S]: „Szczególne emocje budzi instalacja termicznego przekształcania odpadów, która jest mało rozpowszechniona, a dostępne informacje na jej temat w środkach masowego przekazu czy propagowane przez tzw. ekologów zazwyczaj sugerują i wyolbrzymiaja jej szkodliwe oddziaływanie na ludzi i środowisko. Spowodowane jest to głównie brakiem wiedzy o zasadach działania instalacji, o dopuszczalnych wartościach emisji zanieczyszczeń i nieznajomością procedur administracyinych". Zob. Raport ITPOK, Poznań 2010.

${ }^{8}$ Z. Bauman, Wieloznaczność nowoczesna, nowoczesność wieloznaczna, tłum. J. Bauman, Wydawnictwo Naukowe PWN, Warszawa 1995.

${ }_{9}$ Autorka, siłą rzeczy, obracając się w środowisku aktywistycznym, dysponuje sporym zapasem tego rodzaju anegdot, które wprawdzie mogą się czytelnikowi wydać źródłem wiedzy o co najmniej wątpliwej wartości, jednak pozwalają na intuicyjne uchwycenie pewnych problemów i sposobów myślenia, w których zanurzone jest środowisko działaczy społecznych czy ekologicznych. Niezmiennie aktualne pozostaje zresztą założenie Kirsten Hastrup, która badacza uznaje za element pola badań, taki sam jak każdy inny. K. Hastrup, Droga do antropologii. 
„błąd tuby” (tzw. szczekaczki), czyli skupienie się na tym, co jako aktywiści mamy społeczeństwu do zakomunikowania, kosztem „ucha” czyli wsłuchania się w to, co inni mają do powiedzenia nam. Błąd to szczególnie trudny do uniknięcia, gdy owi „inni” jawią się nam jako potencjalna przeszkoda w drodze do realizacji zamierzonych przez nas celów, co niestety, często ma miejsce w wypadku organizacji zajmujących się ochroną przyrody. Nie oszukujmy się - lokalna społeczność ma zwykle zupełnie odmienne spojrzenie na kwestię wykorzystania zasobów środowiska naturalnego niż naukowcy i organizacje ekologiczne. To, co z punktu widzenia ocalenia procesów i miejsc przyrodniczo cennych może mieć ogromne znaczenie, pragmatyczna logika „tubylca” niejednokrotnie odrzuca jako bezużyteczne, pozbawione sensu, a może nawet niezgodne z naturą.

Taki problem dotyczy właśnie obranego przeze mnie obszaru badań obranego zresztą głównie ze względu na ową przepaść pomiędzy interesami lokalnej przyrody a lokalnej społeczności, odmiennie zresztą pojmowanymi przez każdą z zaangażowanych w ową sytuację grup. Mówię tu o Puszczy Białowieskiej - najcenniejszym, z przyrodniczego punktu widzenia, ekosystemie w Polsce (oraz jednym z najcenniejszych w Europie). Z uwagi na swój status biologiczny, Puszcza została uznana za element Światowego Dziedzictwa UNESCO, jak również włączona w sieć Rezerwatów Biosfery (MaB). 0 ile jednak te dwa „tytuły” pełnią czysto prestiżową funkcję, o tyle $23 \%$ obszaru puszczy objęte jest, znacznie bardziej „namacalnymi”, krajowymi formami ochrony (park narodowy wraz z dodatkowymi rezerwatami), z czego $10 \%$ to obszar ochrony ścisłej. Co z resztą? Właśnie o tę resztę toczy się od kilkunastu lat burzliwa dyskusja, angażująca mieszkańców wsi puszczańskich, Lasy Państwowe, Ministerstwo Środowiska, naukowców oraz większość znaczących polskich organizacji ekologicznych.

Gdzie leży powód owego wielostronnego zaangażowania w sprawę Puszczy Białowieskiej oraz niesłabnącej temperatury emocji towarzyszących tej dyskusji? Na najbardziej ogólnym poziomie można uznać, że przyczyną takiego stanu rzeczy jest nieprzystawalność znaczeń, które włączone w dyskusję grupy nakładają na świat przyrody oraz na własne w tym świecie funkcjonowanie. Czym innym jest Puszcza dla pracownika Zakładu Usług Leśnych, czym innym dla entomologa, turysty czy dla aktywisty

O ugruntowywaniu się światów - podstawy empiryczne antropologii, tłum. E. Klekot, [w:] Badanie kultury. Kontynuacje, pod red. M. Kempnego, E. Nowickiej, PWN, Warszawa 2004, s. 97. 
Pracowni na Rzecz Wszystkich Istot. Choć geograficznie jest to ten sam obszar, pod względem semantycznym poszczególne jego „warianty” okazują się być diametralnie różne. Dodatkowym elementem, który należy tu brać pod uwagę, jest ten, że oprócz synchronicznego, waloryzacja przestrzeni ma również wymiar diachroniczny - kształtujący się w toku historycznej interakcji człowieka i przyrody. Znaczenia nie są czymś przypisanym do „tu i teraz" - nakładają się na siebie warstwami, tworząc coś na kształt stanowiska archeologicznego, w którym obecnie widoczne obiekty, są dla nas dostrzegalne dzięki wielu poziomom ziemi i skorup, znajdujących się pod nimi. Tutaj poczynić należy założenie, że choć w trakcie moich badań skupiałam się mocno na Białowieży, przechodząc od części stricte empirycznej do wniosków, będę również angażowała przykłady i przemyślenia z innych obszarów praktyki środowiskowej.

Żeby jednak nie oddalać w czasie tego momentu, na który większość badaczy terenowych z niecierpliwością wyczekuje, przejdę może do metod, jakimi próbowałam do świata znaczeń dotrzeć ${ }^{10}$. Przystępując do badań, uznałam, że w próbach tych niewystarczające będzie odwołanie się wyłącznie do wywiadu swobodnego, w związku z czym postanowiłam podeprzeć się również analizą źródeł zastanych i obserwacją. W kwestii źródeł, obawiam się, daleko mi było do precyzji, z jaką przyglądałby się im historyk czy archiwista, ale mam nadzieję, że nie popełniłam też żadnych rażących zaniedbań warsztatowych. Co zaś się tyczy obserwacji, to prowadzić ją musiałam poniekąd mimowolnie, bo mieszkając w trakcie obu swoich pobytów w Białowieży (robiąc zakupy, uczestnicząc z nabożeństwach w cerkwi i w miejscowych uroczystościach, czyniąc wyprawy na lokalny cmentarz), siłą rzeczy towarzyszył mi przymus obserwacji. Problemem była raczej rejestracja i przetwarzanie tych wszystkich docierających do mnie bodźców. Początkowo przybrałam postawę „sroki” - cokolwiek wyróżniało się w obserwowanej przestrzeni, budząc moje zaskoczenie czy zainteresowanie,było uwieczniane w formie tekstu lub zdjęć, nawet jeśli niejednokrotnie

${ }^{10}$ Lub raczej dotrzeć na tyle, na ile to jest możliwe. To chyba nieustanny dylemat towarzyszący wszelkiego rodzaju badaniom etnologicznym: im bardziej usiłujemy rzeczywistość zmierzyć, tym bardziej ona wymyka się naszym próbom konceptualizacji. Jako osoby pochodzące z zewnątrz badanej kultury, nigdy nie jesteśmy w stanie do końca zrozumieć rządzących nią mechanizmów, które z kolei dla tubylców są przezroczyste - tak codzienne, że aż niewidoczne. Jedyne, co możemy z pomocą etnograficznego warsztatu pracy próbować zrobić, to przybliżyć nieco cudze uniwersum znaczeń i uczynić je zrozumiałym dla nas. 
różne elementy doświadczenia prowadziły mnie w zupełnie różne strony. Z czasem, gdy moje przemyślenia zaczęły się układać w pewne tropy, nastąpiła też większa selektywność zapisów, a przynajmniej większa zdolność przyporządkowania ich do kategorii analitycznych.

Co zaś się tyczy wywiadów, to w miarę możliwości starałam się umawiać z moimi rozmówcami na „pełnometrażowe” rozmowy, w miejscach i czasie sprzyjających takiej rozmowie, jednak mogłabym wskazać również na mniej zorganizowane i zarazem bardziej spontaniczne rozmowy toczące się na przykład ze sprzedawcami pamiątek, czy osobami przypadkowo spotkanymi na ulicy. Jeśli wziąć pod uwagę zarówno jedne jak i drugie ${ }^{11}$, w ramach badań udało mi się zarejestrować około trzydziestu wywiadów, prowadzonych w sposób swobodny, jedynie z luźnymi wytycznymi badawczymi. Starałam się nie dobierać rozmówców pod kątem jakiegoś klucza, chyba, że za klucz taki uznać różnorodność kontekstu, w jakim są zanurzeni. W większości, z uwagi na obranie Białowieży jako terenu badań, byli to właśnie białowieżanie. Jeśli przyjąć jednak Marcusowski postulat etnografii wielostanowiskowej ${ }^{12}$, wówczas podmiot badań nie musi być tak ściśle związany z miejscem, jeśli jego doświadczenie wiąże się ściśle z tych badań przedmiotem. Stąd oprócz wypowiedzi rodowitych mieszkańców, zbierałam także opinie osób pochodzących skąd indziej i osiedlonych tutaj (tzw. nawołocz), jak również (choć w mniejszym stopniu) takich, które wprawdzie nie zamieszkują w Białowieży, ale związane są z nią chociażby za sprawą działań prowadzonych na rzecz Puszczy.

Takie połączenie różnych technik badawczych nie tylko umożliwiło triangulację uzyskiwanych danych, ale też przyczyniło się do zwiększenia

${ }^{11}$ Rozgraniczenia między wywiadami „pełnometrażowymi a „okazjonalnymi” nie decyduję się przeprowadzać, ponieważ granica między nimi okazuje się być bardzo płynna. Nierzadko przypadkowa pogawędka przeradzała się w długą rozmowę, dostarczając mi wartościowego materiału badawczego. W takich sytuacjach nieczęsto udawało mi się uzyskać zgodę na nagrywanie i musiałam poprzestać na notatkach. Jeśli jednak za kryterium wartościowości uznać przewagę nagrania nad zapisem, wówczas łatwo doszlibyśmy do absurdu, związanego z przedkładaniem technologii nad doświadczeniem. Oznaczenie Not. przy cytowaniu zebranych materiałów, stosuję zaledwie tam, gdzie rzeczywiście chodzi o jedno lub dwa zdania wyciągnięte z całej rozmowy, które jednak wydały mi się być na tyle znamienne, że warte zamieszczenia w gotowej pracy.

12 G. Marcus, Użyteczność kategorii uczestnictwa w zmieniających się kontekstach antropologicznych badań terenowych, [w:] Clifford Geertz - Lokalna lektura, pod red. D. Wolskiej, M. Brockiego, Wydawnictwo UJ, Kraków 2002, s. 155-181. 
orientacji w badanej rzeczywistości i do nakreślenia swego rodzaju mapy, z pomocą której usiłowałam poruszać się po obcym dla siebie terenie. Gdybym jednak miała ową mapę nakreślić czytelnikowi, musiałoby to być właściwie kilka różnych map w zależności od tego, kto o danym terenie opowiada. Choć jednak takie zróżnicowanie występuje, trudno tu o łatwe podziały między „przeciwnikami” a „zwolennikami” poszerzenia Parku Narodowego. Znacznie lepiej byłoby widzieć ową dywersyfikację jako swego rodzaju kontinuum, na którego krańcach występują Weberowsko pojmowane typy idealne ${ }^{13}$ : ogrodniczy i biocentryczny. Pomiędzy nimi rozpościera się jednak całe spektrum postaw i działań, będących wynikiem ścierania się sfery znaczeń i wartości ze społeczną praxis.

W swojej „czystej” postaci postawa ogrodnicza odnosi nas do wspominanej tu już Baumanowskiej nowoczesności, gdzie świat jawi się jako maszyna, którą należy precyzyjnie operować, jako potencjalne źródło chaosu, którego pojawieniu się winniśmy przeciwdziałać. Chaotyczny jest z założenia świat natury-rządzący się własnymi, innymi niż ludzki, prawami..,Zabałaganiona” jest tym bardziej Puszcza Białowieska, gdzie w częściach wyłączonych spod dominacji człowieka, natura rządzi niepodzielnie, lekceważąc cywilizacyjną potrzebę porządku. Niezgodność takiego stanu z własnymi wyobrażeniami o funkcjach przyrody, przekłada się na odczucia estetyczne: „Nic mi się tam nie podoba. Tam tylko to leży wszystko, tylko to leży. Widziała pani, była pani w rezerwacie? No i co tam się dzieje? Sodoma i Gomora”"14.

Określenie „rezerwat” odnosi się tu do rezerwatu ścisłego, który choć nie obejmuje całości terenu Puszczy czy nawet Parku Narodowego, w powszechnej świadomości tak właśnie funkcjonuje. Jedna z moich rozmówczyń wyjaśnia ten stan rzeczy następująco:

Park Narodowy został stworzony w 1921 roku i zaraz potem postawiono płot i zabroniono wchodzić i cały Park Narodowy to wtedy był rezerwat ścisły. (...) Więc w głowach mieszkańców to funkcjonuje jako teren zamknięty, zakazany i jeszcze ogrodzony płotem. Cały Park Narodowy. Nawet jak otworzono go w 1996 i powiększono o tą część północną i tu od wschodu, to dla mieszkańców Białowieży ciągle jest niedostępny. Bo nasza bezpośrednia granica z Parkiem to jest rezerwat ścisły, do którego nie możemy wchodzić ${ }^{15}$.

${ }^{13}$ M. Weber, Obiektywność poznania w naukach społecznych, tłum. M. Skwieciński, [w:] Problemy socjologii wiedzy, pod red. A. Chmieleckiego PWN, Warszawa 1985, s. 45-100.

${ }^{14}$ WW MS/02.01.2012d.

${ }^{15}$ WW MS/06.01.2012b. 
Pojawia się tu wizja lasu „zamkniętego” - ogrodzonego płotem, wyłączonego z gospodarowania, a zatem w pewien sposób, nieuży tecznego. Symboliczna figura zamknięcia, wzmacniana jest przez realnie istniejące ogrodzenie, czy przez bramę wejściową do rezerwatu, za którą wstęp można uzyskać tylko w towarzystwie przewodnika. Skoro zaś coś nie podlega naszemu użytkowaniu, zapewne się marnuje:

Ale ktoś tam wyliczył, że te leżące drzewa, które można by komuś czy sprzedać, nawet i na opał ludziom. Opał przecież bardzo drogi jest. A wiele jest takich rodzin, których nie stać w ogóle nawet na kupienie drewna. Można by im to oddać. No ale to ma zgnić, to ma leżeć ${ }^{16}$.

W tym wypadku sprawa jest zresztą bardziej skomplikowana, bo ogrodnicze podejście charakterystyczne dla nowoczesności, łączy się z charakterystycznym dla rejonów niezbyt zasobnych materialnie pragmatyzmem, w myśl którego faktycznie marnowanie czegokolwiek okazuje się być dużym wykroczeniem przeciwko przyjętemu systemowi wartości. Marnowanie zaś, oznacza przede wszystkim niewykorzystanie przez ludzi. Korzyści dla natury są wartością abstrakcyjną, bowiem natura to raczej przedmiot niż podmiot, służący zaspokajaniu ludzkich potrzeb, a nie generujący własne. Poza tym: „Na szczycie drzewa życia siedzi człowiek” - przekonuje przed kamerą dyrektor Parku Bieławieżskaja Puszcza ${ }^{17}$. Nie robak, chciałoby się dodać, bo w jakże wielu wypowiedziach moich rozmówców pojawia się motyw drewna rzuconego na pożarcie chrząszczom oraz żuczków, które mają w Puszczy większe prawa niż ludzie. W tym układzie, aktywiści ekologiczni jawić się muszą nieuchronnie jako sprzymierzeńcy chrząszczy i żuczków oraz wrogowie świata ludzi. Obcość jest wpisana w sam status osób opowiadających się „po stronie przyrody”. Przyrodę, owszem, chronić należy, ale w sposób czynny, to znaczy taki, który umożliwia ciągłą ingerencję człowieka w ekosystem. Natura jest ogrodem, o który trzeba zadbać, bo inaczej uschnie lub zarośnie chaszczami. Naturę należy pielęgnować i wykorzystywać, a nie pozostawiać samej sobie.

Inaczej jest w dyskursie biocentrycznym. Tu dychotomia człowiek-natura rozmywa się i traci na znaczeniu. Zamiast drzewa życia, czy też drabiny bytów, z człowiekiem na samym szczycie, preferuje się raczej metaforę

${ }^{16}$ WW MS/05.05.2012a.

${ }^{17}$ Reportaż o Puszczy Białowieskiej, Telewizja ONT, 2011, http://www.youtube.com/ watch?v=0ZJ0Lyq_OMk, (dostęp: 15.10.2012). 
kręgu czy sieci, w której wszystkie elementy są ze sobą powiązane w sposób niehierarchiczny. Tutaj pojawiać się mogą wypowiedzi, które godzą w same podstawy ogrodniczego systemu wartości: „Dobrze, że przynajmniej w BPN kornik jest naturalnym członkiem społeczności leśnej, skoro w pozostałych parkach narodowych jest »szkodnikiem «"18. Nie znaczy to, że rezygnuje się tu z potrzeb człowieka, ale są one rozpatrywane w powiązaniu ze wszystkimi innymi przedstawicielami świata żywego. Nielubiany przez leśników kornik okaże się w podejściu biocentrycznym zaledwie jednym z elementów ogromnej sieci zależności, w którą zaplątany jest również człowiek. Sieć ta rozciąga się zresztą zarówno w przestrzeni, jak i w czasie - stąd dążenie do zachowywania procesów raczej niż poszczególnych gatunków i siedlisk. Dries Kuijper z Instytutu Biologii Ssaków PAN, rozmawiając z Adam Wajrakiem, zauważa:

Oczywiście my, ludzie, jesteśmy bardzo niecierpliwi. Patrzymy na las z perspektywy naszego życia albo krótszej - 30-40 lat pracy w jednym miejscu, takim jak park narodowy lub nadleśnictwo. Tymczasem rosnące tu drzewa takie jak dęby, mogą żyć nawet kilkaset lat. To jest ich perspektywa czasowa. W Puszczy Białowieskiej mamy wszystko, co trzeba, żeby funkcjonowała bez ingerencji ze strony człowieka ${ }^{19}$.

Skoro zaś akcent zostaje przeniesiony raczej na perspektywę ekosystemową niż ludzką, również ochrona będzie wymagała bardziej wycofania ingerencji ludzkiej z naturalnych procesów, niż uważnego ich kontrolowania. To również pozostaje niezrozumiałe dla aktywnego Kartezjańskiego podmiotu: jak może w ogóle istnieć coś takiego jak ochrona bierna? Jak można coś chronić, nic nie robiąc? Obok tego zaś, pojawia się kolejne pytanie: jak można chronić coś, co nie ma żadnego (praktycznego) znaczenia dla ludzi? Otóż można, bowiem - jak czytamy w wypowiedzi, która dobrze oddaje ducha biocentryzmu, dzika przyroda: „Jest wartością samoistną, niezależną od jej użyteczności dla człowieka"20. Jeżeli zaś zderzymy tę postawę ze skrajnie różnym światopoglądem, w myśl którego przyroda nie tylko istnieje

${ }^{18}$ J. Korbel, Puszcza Białowieska (blog internetowy), 25.08.2011, http://puszczabialowieska.blogspot.com/, (dostęp: 15.10.2012).

${ }^{19}$ D. Kuijper, A. Wajrak, Puszcza Białowieska: oby tylko człowiek jej nie przeszkadzat, Wyborcza.pl, http://wyborcza.pl/1,75476,10935787,Puszcza_Bialowieska_oby_tylko_czlowiek_jej_nie_przeszkadzal.html, (dostęp: 15.10.2012).

${ }^{20}$ T. Wesołowski, G. Bożek, Puszcza jest naszq rafą koralowq - z prof. Tomaszem Wesołowskim rozmawia Grzegorz Bożek. „Dzikie Życie” 2005-2006, nr 12-1, http://pracownia.org.pl/ dzikie-zycie-numery-archiwalne,2137,article,2759, (dostęp: 15.10.2012). 
dla człowieka, ale też dzięki człowiekowi i bez niego z pewnością nie da sobie rady, wówczas łatwo zorientujemy się, że różnica zdań między zwolennikami jednego i drugiego systemu wartości, jest jednak czymś więcej niż czysto kosmetycznym niuansem. Bez uwzględnienia tej różnicy w procesach planowania ochrony środowiska naturalnego, nie będziemy w stanie wykroczyć poza poziom czysto technicznych rozwiązań, sięgających instytucji i regulacji, a nie idei i wartości.

Kolejnym czynnikiem, którego w takich procesach zdecydowanie pomijać się nie powinno, jest czas. Nasze myślenie o przyrodzie jest uwarunkowane historycznie. Marshall Sahlins określa tę prawidłowość mianem ryzyka w kategorii w działaniu ${ }^{21}$, zwracając uwagę, że osadzenie ludzkich działań w czasie podlega dwóm uzupełniającym się procesom. Po pierwsze - na nasze obecne postępowanie ma wpływ zastany kontekst historyczny (struktura), po drugie zaś - sama struktura ulega drobnym modyfikacjom pod wpływem bieżących doświadczeń. Każde miejsce ma swoją historię i rozpatrywanie tego, co dzieje się „tu i teraz” w oderwaniu od niej, da nam co najmniej niepełny obraz sytuacji. Rzecz jasna, są w dziejach każdej grupy momenty i przedziały czasowe bardziej lub mniej znaczące z symbolicznego punktu widzenia. Ja skupiłam się na tych elementach historycznej narracji, w których dopatrywałam się związków z obecnym podejściem mieszkańców Białowieży do Puszczy i do jej ochrony. Bardziej jednak niż punktowo należałoby je traktować w przedziałach i ciągach czasowych. Znaczenia bowiem nie wykuwają się zdarzeniowo, a periodycznie. Stanowią one pewien pretekst, zaczątek dla czegoś, co wokół nich rozwija się i narasta.

Niewątpliwie, jednym z takich elementów historycznej narracji, który rozpoczął zawrotną karierę Białowieży jako miejsca pobytów elit, było osławione Wielkie Polowanie króla Władysława Jagiełły z 1409 roku. Epizod do tej pory pojawia się w zbiorowej pamięci, czy to w formie toponimów: Dąb Jagiełły, Tryb Jagielloński, Uroczysko Jagiellońskie itd., czy też w postaci, odwołujących się doń, hucznych imprez plenerowych. Okres „królewski” uczynił z miejscowości swego rodzaju oczko w głowie możnowładców, którzy z lubością pojawiali się tutaj, by oddawać się łowom na grubego zwierza. Paradoksalnie, to właśnie umiłowanie władców dla polowań, stało się przyczyną zachowania Puszczy w takim kształcie, w jakim znamy ją obecnie.

${ }^{21}$ M. Sahlins, Struktura a historia, [w:] Wyspy historii, tłum. I. Kołbon, Wydawnictwo UJ, Kraków 2006, s. 160-161. 
Bardzo wcześnie bowiem dokonane zostało formalne rozdzielenie dóbr puszczańskich na własność prywatną i własność książęcą ${ }^{22}$. Ta ostatnia, przeznaczona głównie pod tereny łowieckie, wolna była od eksploatacji przez miejscową ludność - od intensywnej gospodarki leśnej czy od kłusownictwa. Nad zachowaniem książęcych przykazań i obsługą polowań czuwali mężczyźni zatrudniani w charakterze osoczników, strażników i strzelców. Co istotne, rekrutowali się oni spośród miejscowej ludności, co sprawiało, że królewskie wymogi i obostrzenia przestawały być uznawane wyłącznie za coś zewnętrznego, skoro egzekwowane były przez „swoich”. Do takiego ich pojmowania przyczyniało się również i to, że, jakkolwiek surowe, nakazy i zakazy wiązały się jednak z pewnymi przywilejami. Mieszkańcy puszczańskich wsi otrzymywali od władców przywilej tzw. wchodów do Puszczy, które, jak czytamy w jednej z publikacji, stanowiły: „zezwolenia na użytkowanie zasobów leśnych, w formie m.in. sianożęć błotnych, bartnictwa czy łowienia ryb"23. Zakaz wstępu do Puszczy nie był zatem absolutny, zaś odstępstwa od niego nadane nie przez byle kogo, bo przez samego króla. Nic zatem dziwnego, że dziś jeszcze królewskie przywileje traktowane bywają nie w sposób historyczny, czy symboliczny, ale zupełnie realny. W trakcie wymiany zdań między przyrodnikiem Adamem Bohdanem a pracownikiem Zakładu Usług Leśnych, ten ostatni tłumaczył Bohdanowi, że: „....jego ród ma specjalne prawa do eksploatacji Puszczy, a konkretnie do wycinki i bartnictwa. Zostały one (...) nadane jego przodkom przez króla Władysława Jagiełłę, tylko dokumenty gdzieś się zagubiły"24. Widzimy zatem, że struktury długiego trwania mają nie tylko symboliczny, ale jak najbardziej bezpośredni wpływ na obecną świadomość mieszkańców wsi puszczańskich. Królewskie edykty sprzed kilkuset lat grają w zbiorowej pamięci większą rolę niż jakiekolwiek współczesne akty i dokumenty. Należy się dopatrywać w tym czegoś więcej niż czysto pragmatycznego wykorzystania zdarzeń historycznych na potrzeby bieżących okoliczności. Musi być w okresie królewskim coś, co sprawia, że właśnie na

${ }^{22}$ Piotr Bajko sugeruje, że stało się to w już w 1387 roku. P. Bajko, Z dawnej Białowieży, Wydawnictwo Hajstra, Otwock-Białowieża 2010, s. 5.

${ }^{23}$ B. Jędrzejewska, Cz. Okołów, T. Samojlik, Dziedzictwo zobowiq̨zuje. 600 lat ochrony Puszczy Białowieskiej. Materiały Międzynarodowej Konferencji Naukowej, Białowieża, 11-12 września 2009, Ministerstwo Środowiska, Warszawa 2010, s. 40.

${ }^{24}$ A. Bohdan, Będziem topić w bagnie. „Dzikie Życie” 2010, nr 6, http://pracownia.org.pl /dzikie-zycie-numery-archiwalne,2253,article,5035, (dostęp: 15.10.2012). 
niego powołują się w swojej narracji mieszkańcy. Co to takiego, skoro wtedy, podobne jak teraz, Puszcza była w znacznym stopniu zamknięta przed użytkowaniem? Wskazać tu można kilka czynników, które się do pozytywnej oceny ówczesnego stanu rzeczy przyczyniały. Pierwszym z nich jest wspomniana już kwestia współwłasności i współodpowiedzialności, objawiająca się w przyznawaniu wchodów do Puszczy i w ustanawianiu miejscowych strażnikami królewskiej własności. Kolejny to prestiż związany z samymi pobytami elit. Wreszcie - królewska wizja ochrony w znacznym stopniu wpisywała się w miejscowy system wartości. Dualizm: chronić, ale wykorzystywać (chociażby w trakcie polowań) rezonował w zbiorowej świadomości, w której marnowaniem puszczańskich zasobów byłaby ochrona dla samej ochrony.

Kolejnym ważnym etapem w historii Białowieży jest okres carski. W dalszym ciągu istnieje w tym czasie tendencja do traktowania tego obszaru jako „kurortu” dla elit. Dzieje się tak tym bardziej, że w same wizyty cara wpisana jest poetyka pewnego zbytku, nadmiaru, teatru. Ważne jest tutaj również podejście do figury władcy, które jak wskazują badacze, jest charakterystyczne dla całego rosyjskiego prawosławia ${ }^{25}$. Zwraca na nie uwagę również Ryszard Kapuściński, który w „Imperium” opisuje tę prawidłowość następująco:

Car uważany jest za Boga i to w sensie dosłownym. Przez stulecia, przez całą historię Rosji. Dopiero w XIX wieku wydano ukaz carski, aby zdjąć z cerkwi portrety cara. Ukaz carski! Bez niego nie ośmieliłby się nikt tknąć takiego portretu - ikony. (...) Car jest Bogiem - w tej dwoistej naturze Władzy Najwyższej w Rosji leżała jej stabilność, trwałość i siła. (...) Car był wysłannikiem i pomazańcem Wszechmogącego, więcej - był jego uosobieniem, ziemskim odbiciem. Tylko ten, kto utrzymywał (i jakoś to udowadniał), że jego władza ma bosko-ludzką naturę, mógł tu sprawować rządy, prowadzić za sobą lud, liczyć na jego posłuszeństwo i oddanie ${ }^{26}$.

W jaki sposób ta refleksja polskiego reportera znajduje odzwierciedlenie w warunkach (rdzennie białoruskiej i wciąż w siedemdziesięciu procentach prawosławnej) współczesnej Białowieży? Chociażby poprzez sentyment, z jakim część jej mieszkańców wspomina czasy carskie nawet, jeśli sami ich nie pamiętają:

${ }^{25}$ J. Keller, Prawosławie, Iskry, Warszawa 1982, s. 148-149.

${ }^{26}$ R. Kapuściński, Imperium, Czytelnik, Warszawa 1993, s. 91-109. 
mówiło się - był car, był porządek. I nawet nie tylko w takim sensie, że dyscyplina, że ten ordnung, ale że po prostu ludzie musieli dbać o czystość obejść. Że jak miał przyjechać car, to chodzili inspektorzy i kazali naprawiać płoty, sprzątać obejścia itd. (...) Nawet jak turyści dzisiaj przyjeżdżają, to mówią, że faktycznie te obejścia są tutaj takie wyjątkowo czyste i ładne ${ }^{27}$.

Inny przykład odnosi się już bezpośrednio do figury cara jako wielkiego hospodina:

...błędem było zlikwidowanie pałacu carskiego - bo to była istna perełka - nie chodzi tylko o sam budynek, który był piękny, ale o więź materialną z historią. Z historią, ale i z wielkością cara, który jaki by nie był, to był wielki ${ }^{28}$.

Takich opinii pojawia się więcej, a nawet tam, gdzie nie ma mowy o carze bezpośrednio, powracającym motywem jest figura dobrego gospodarza czy to w odniesieniu do leśników, którzy wiedzą, jak należy opiekować się Puszczą, czy wręcz Aleksandra Łukaszenki, którego postać zostaje wpisana w ojcowski rys władcy i opiekuna. Kontrastem dla gospodarza dobrego jest oczywiście gospodarz zły, czyli Minister Środowiska, który w powszechnej opinii nie jest w stanie chronić Puszczy tak, by zadbać o interesy mieszkańców albo też - podległy Ministrowi - Park Narodowy, którego niegospodarność jest wytykana na każdym kroku ${ }^{29}$ :

Ale Park za bardzo też nie daje rady z tą połacią, którą ma. Nie ma porządku. Ja to widzę, nawet patrząc tutaj, na Park Pałacowy. Sąsiedztwo moje. Już nie mówiąc o Parku puszczańskim. Więc wydaje mi się, że oni powinni tutaj porządek pokazać. Pokazać jako gospodarz dobry, że to coś fajnego, że my tu robimy, dbamy. Dbają troszeczkę, ale nie tak. Za mało. Zaniedbany jest park ${ }^{30}$.

Współcześni gracze w tym symbolicznym dyskursie nakładani są na historyczną siatkę znaczeń, zaś ich działania odczytywane są nie tylko w kontekście teraźniejszym, ale i w konfrontacji ze wspaniałą przeszłością Białowieży. Stwierdzenia, które bez znajomości kontekstu dziejowego, wydać się mogą niezrozumiałe czy śmieszne, w zetknięciu z nim zyskują

${ }^{27}$ WW MS/05.01.2012b.

${ }^{28}$ WW. MS/06.01.2012a.

${ }^{29}$ Nie bez kozery zresztą, bowiem dotychczasowe zarządzanie Białowieskim Parkiem Narodowym pozostawia wiele do życzenia. Chroniczne kłopoty finansowe, ciągłe zmiany dyrektorów i brak ciągłości w polityce kierowania Parkiem, nawet jego zwolenników skłaniają do niezbyt pochlebnych opinii na ten temat.

${ }^{30}$ WW MS/05.05.2012a. 
nowy rys, który również powinien być brany pod uwagę w praktyce zrównoważonego rozwoju.

W Białowieży takie odczytanie równoczesne ma znaczenie również z uwagi na jej dzieje stosunkowo najnowsze, kiedy to przez swój pograniczny charakter, stała się ona przechodzącym z rąk do rąk, polem wojskowych manewrów. W czasie samej tylko II wojny światowej Białowieża czterokrotnie zmieniała swą przynależność państwową, a każda zmiana wiązała się z ogromnymi stratami w ludziach i zniszczeniami infrastruktury. Piotr Bajko w swoim opracowaniu o dziejach miejscowości wspomina, że w hitlerowskich egzekucjach straciło tu życie około tysiąca osób, zaś kolejne półtora tysiąca zostało przesiedlone w głąb Związku Radzieckiego ${ }^{31}$. Wśród tych ostatnich znaleźli się w głównej mierze przedstawiciele administracji leśnej i ich rodziny, co na trwałe wpisało tę, już i tak dość dobrze wrośniętą w miejscową społeczność, grupę zawodową, w białowieską martyrologię. Zdarzenia te są z naszego punktu widzenia o tyle znamienne, że współcześnie w dyskursie osób związanych z ochroną Puszczy, dość często pojawia się przeciwstawienie „dobrych mieszkańców” i „złych leśników”, które z dziejowego punktu widzenia, wydaje się być co najmniej nietrafne.

Co istotne $\mathrm{w}$ tym momencie to, że historyczne zawieruchy wpłynąć mogły na jeszcze jeden charakterystyczny element w podejściu mieszkańców tych terenów do obowiązującej władzy, ale i w ogóle do wszystkiego, co przychodzi z zewnątrz. Tutejsza społeczność miała niemały orzech do zgryzienia. Z jednej bowiem strony - jako centrum życia towarzyskiego elit - Białowieża musiała dbać o jak najlepsze owych elit przyjęcie (wizyty zaś obejmowały nie tylko polski ród Jagiellonów czy carską rodzinę Romanowów, ale również prezydenta Ignacego Mościckiego, a także znacznie mniej pożądanych gości, jak choćby Heinrich Himmler czy Nikita Chruszczow). Z drugiej zaś - jako obszar geograficznie peryferyjny - miejscowość niejednokrotnie stawała w ogniu walczących ze sobą wojsk i zmieniających się ustrojów. Niełatwo w takiej sytuacji o chwytanie za broń, ilekroć w oddali zamajaczą kolejne żołnierskie mundury. Niełatwo również o łatwą identyfikację narodową, której czasem może lepiej nawet unikać w obliczu ciągłych politycznych represji.

31 P. Bajko, dz. cyt., s. 21. 
Wyróżnia tych ludzi [mówi o białowieżanach jeden z moich rozmówców, również rodowity mieszkaniec tego miejsca] taka spolegliwość, czyli godzenie się na pewne warunki życia, godzenie się na jakąś tam władzę i jakby ta nacja nigdy nie była bardzo rewolucyjna, nigdy też bardzo mocno nie walczyła o swoje prawa ${ }^{32}$.

Ten brak tendencji „rewolucyjnych” czy apolityczność, nie oznaczają jednak braku poczucia własnej godności, tożsamości, czy braku jakiegokolwiek stanowiska w sprawach elementarnych. Jest jednak cechą dość charakterystyczną dla pogranicza, że owa tożsamość nie daje się tu zamknąć w prostych kategoriach narodu, religii, ideologii. Tutaj mniejsze znaczenie ma, czy jesteś Polakiem czy Białorusinem, katolikiem czy prawosławnym. Ważniejsze, czy jesteś „tutejszy”. Jeśli bowiem nie jesteś, to znaczy, że jesteś albo „nawołocz” albo „matany”33, przy czym oba te określenia posiadają wymiar silnie pejoratywny. „Tutejsi, białowiescy” są ci, którzy się tu urodzili, ale też wyznają system wartości zbliżony do miejscowego. Ktoś, kto mieszka tu od dwudziestu lat, ale pochodzi skąd indziej, może wprawdzie zostać oswojony, ale nie uznany za swego. Swój może obchodzić Święta w obrządku prawosławnym lub katolickim (a bardzo często w jednym i w drugim), ale raczej nie będzie popierał postulatów poszerzenia Parku Narodowego. Owo rozróżnienie jest nasilone do tego stopnia, że jak wspomina w swoim opracowaniu Piotr Gliński:

Dyrektor parku podczas oprowadzania grupy studentów socjologii po Rezerwacie Ścisłym (12.09.2000) przyznał, ze choć urodził się i spędził dzieciństwo w Białowieży, przez białowieżan traktowany jest jako „nawołocz”. Do wykluczenia z grona „swoich” - jak sądzi - wystarczył stosunkowo krótki pobyt na studiach poza Białowieżą lub decyduje o tym pozycja, którą zajmuje obecnie ${ }^{34}$.

Podział ten wspominam z konkretnej przyczyny. Jeśli bowiem spróbujemy się zagłębić w istotę sporu o kształt ochrony Puszczy Białowieskiej, ukaże się on naszym oczom z całą jaskrawością. Nie będzie dziwić nas podejrzliwość już nie tylko w stosunku do, bywających tu sporadycznie, aktywistów ekologicznych, ale nawet do, mieszkających w Białowieży od wielu lat,

32 WW MS/01.05.2012.

${ }^{33}$ Określenie nawołocz odnosi się do przybyszów z miasta, spoza terenu Podlasia. Matany to pogardliwa nazwa dla osób, które przeprowadziły się do Białowieży z terenu Podlasia, najczęściej z jednej z okolicznych wsi (która to przeprowadzka w czasach świetności tego miejsca, było uznawane za źródło prestiżu ekonomicznego i społecznego).

${ }^{34}$ P. Gliński, Konflikt o Puszczę. Raport z badań nad konfliktem społecznym dotyczącym poszerzenia Białowieskiego Parku Narodowego, [w:] Pogranicze. Studia Społeczne, pod red. A. Sadowskiego, Wydawnictwo Uniwersytetu w Białymstoku, Białystok 2002, s. 85. 
naukowców z Zakładu Badania Ssaków PAN. Wszyscy oni są w myśl miejscowego systemu wartości obcy, więc należy zachowywać dystans i podejrzliwość wobec ich poczynań.

Podejrzliwość ta nasila się jeszcze bardziej, gdy obcy co chwila popełniają podstawowe błędy komunikacyjne. Nawet Wojciech Cejrowski, stanowiący dla autorki tej pracy typ mocno etnocentryczny, nie zaniedbuje w trakcie swych wypraw rozpoznania lokalnych kontekstów i prób wcielenia ich we własną praktykę podróżniczą (i pewnie dlatego, przy całym swym zadufaniu, jeszcze żyje). Tymczasem zarówno Ministerstwo Środowiska, jak też większość organizacji ekologicznych, które dotąd miały okazję działać na rzecz Puszczy Białowieskiej, dbały wprawdzie o dobry PR zewnętrzny (w ogólnopolskich mediach), jednak wewnętrznego (w kontakcie z lokalną społecznością) zaniechały w zupełności. Nie miejsce tu, by przytaczać cały przebieg sprawy puszczańskiej tak na poziomie lokalnym jak i globalnym, ale pozwolę sobie na wymienienie kilku podstawowych błędów ze strony polityków i obrońców przyrody ${ }^{35}$, które się w obrębie owej sprawy pojawiały, stojąc w konflikcie z przyjętym tu przeze mnie rozumieniem zrównoważonego rozwoju.

Pierwszy i zarazem najszerszy z nich, określam jako błąd niedostosowania. Przebiega ono na zarówno na płaszczyźnie poziomej (współcześnie istniejące systemy wartości i znaczeń), jak i pionowej (ich historyczne uwarunkowania). Niedostosowanie odnosi się do nieznajomości lokalnych wzorców czasu, przestrzeni, miejscowego systemu wartości oraz społecznie akceptowanych sposobów działania. Przykłady chronologicznej nieadekwatności, bogato przytaczane przez Edwarda Halla w Tańcu życia w odniesieniu do amerykańskich dyplomatów ${ }^{36}$, można by z powodzeniem wzbogacić o te związane z wizytami w Puszczy aktywistów ekologicznych. Czy to bowiem ze względu na peryferyjność Białowieży i Podlasia jako takiego, czy też na silne osadzenie działań ludzkich w przyrodzie, białowieski model funkcjonowania w czasie jest znacznie wolniejszy niż ten znany nam z Polski centralnej. Może to wprawdzie brzmieć, jak polski orientalizm, gdzie Polska wschodnia zostaje sprowadzona do niespiesznego rytmu życia

${ }^{35}$ Grup tych nie stawiam na równi ani jeżeli idzie o intencje, ani o sposoby działania. Wspominam jednak o ich praktykach, bowiem jako zewnętrzne wobec Białowieskiej społeczności, a zarazem mające znaczny wpływ na jej los, powinny w mojej opinii, zachowywać pewne standardy działania, które sprzyjałyby raczej zmniejszaniu niż eskalacji konfliktu.

${ }^{36}$ E. Hall, Taniec życia, tłum. R. Nowakowski, Muza, Warszawa 1999. 
rodem z filmów U Pana Boga za piecem, jednak poparte jest wypowiedziami samych mieszkańców Podlasia. Odnosząc się do niechęci, z jaką spotykają się akcje ekologów w obronie przyrody, mój rozmówca z Hajnówki zamyśla się i mówi:

Co nagle, to po diable. Na wszystko trzeba poczekać. Tak samo jest z takimi decyzjami. Kiedy wkraczają tam ludzie bardzo aktywni, dla których już nie ma: jutro, tylko cały czas: działamy, działamy, działamy - no, dla nich to może być troszeczkę zbyt pochopne ${ }^{37}$.

Ten pośpiech ekologów objawiać się może, w myśl miejscowego systemu wartości, w domaganiu się błyskawicznych decyzji ze strony rządu czy Ministra Środowiska, a także do haseł, które się owych decyzji domagają: „Czas na ochronę Puszczy. Stop wycince"38. Dlaczego właśnie teraz? - może się zastanowić przezorny białowieżanin, któremu w dodatku nieobce są historyczne losy Puszczy:

nie dzieje się teraz aż tak źle w tej Puszczy, w porównaniu do tego, co się działo kiedyś. Kiedyś Puszcza była dużo bardziej wycinana niż obecnie. Były takie okresy naprawdę czarne w historii Puszczy, więc teraz to pozyskanie drewna jest minimalne i to nie jest nic co by tą Puszczę krzywdziło. (...) Puszcza zawsze się odrodzi. I nawet po tych wszystkich ranach zadawanych przez człowieka Puszcza się odradzała i jakoś sobie radziła, więc teraz może też jakoś tak szybko nie zginie, jak to niektórzy chcieliby jej wieścić39.

Mieszkańcy bardzo często odwołują się również w swoich wypowiedziach do spokoju. Kiedy mówią o wartościach szczególnie cennych dla białowieżan albo o cechach charakterystycznych ich miejscowości, prawie zawsze, wcześniej czy później pojawia się ten spokój. Stąd również sam mechanizm działania aktywistów, w oparciu o akcje bezpośrednie i głośną kampanię medialną, budzić może uzasadniony sprzeciw społeczności lokalnej. Skoro coś uderza w sam rdzeń systemu wartości - w opisywane przez Pawła Schmidta wartości centralne ${ }^{40}$, również reakcja na taki „atak” będzie wykraczała poza poziom chłodnej merytorycznej dyskusji, wkraczając na poziom emocji i wartościowania. Widać to było chociażby w „antyekolo-

37 WW MS/01.2012.

${ }^{38}$ A. Fydrych, Puszcza Białowieska - „Stop wycince!”, http://serwisy.gazetaprawna.pl /ekologia/artykuly/352235,puszcza_bialowieska_stop_wycince.html, (dostęp: 31.05.2013).

39 WW MS/05.01.2012b.

${ }^{40}$ P. Schmidt, „Centralność” i „pogranicznośc”. Dwa modele tożsamości, „Lud”, t. 86, 2002, s. 173-194. 
gicznych" protestach mieszkańców, gdzie wśród haseł manifestantów, pojawiały się nawoływania bardzo emocjonalne, jak: „Unijni Judasze precz!”, czy „Adsiul nasz rod. My choczem tut żyć i pracować najdalej”11.

Pytanie, czy niedostosowanie wynika wyłącznie z braku wiedzy na temat miejsca, do którego się przyjeżdża (wówczas jest do nadrobienia), czy może raczej z braku chęci, by ową wiedzę zgłębiać.

Ponad pół roku od obrony pracy magisterskiej, skłaniam się ku opinii, że to bardziej o brak chęci niż o brak możliwości idzie. W działaniach na rzecz Puszczy dominuje strategia informacyjna raczej niż rozumiejąca oraz komunikacja jednostronna, nastawiona na własny przekaz, a nie na wysłuchanie drugiej strony. Kiedy w wewnętrznej komunikacji jednej z grup zajmujących się ochroną Puszczy ${ }^{42}$, dokonuje się porównania leśników do Scrooge’a z Opowieści Wigilijnej, a całą sprawę do XIX-wiecznego moralitetu, w którym dobro (czytaj: organizacja ekologiczna) triumfuje, możemy mieć niejasną intuicję, że woli zrozumienia na pewnym poziomie jednak zabrakło. Podobnie, gdy w wypadku akcji przeciwko polowaniom na terenie Puszczy Białowieskiej, oficjalny komunikat prasowy brzmi:

Mieszkańcy puszczańskich miejscowości, dzięki obecności turystów, którzy przyjeżdżają podziwiać przyrodę Puszczy Białowieskiej, mają korzyści finansowe. Mamy nadzieję, że żenujący incydent, do którego doszło wczorajszej nocy, nie jest głosem mieszkańców tych okolic ${ }^{43}$.

Nikt, rzecz jasna, nie pyta mieszkańców, czy „żenujący incydent” jest ich głosem ani jak się zapatrują na swoje korzyści finansowe, bo przecież wszyscy doskonale wiedzą, co myślą mieszkańcy oraz jak ich uszczęśliwić. Na poziomie werbalnym, często pojawiają się w sprawie Puszczy takie określenia jak: „lokalna społeczność” czy „mieszkańcy tych terenów” (używane przez wszystkich znaczących graczy w tej dyskusji: zarówno polityków i organizacje przyrodnicze, jak też administrację Lasów Państwowych czy samorządowców). Przyglądając się tym wypowiedziom, musimy jednak nieuchronnie dojść do wniosku, że wszelkie tego typu odwołania mają

${ }^{41}$ P. Gliński, dz. cyt., s. 68. Użycie przez protestujących języka białoruskiego sugeruje tutaj bardzo głęboki (bo sięgający samych podstaw tożsamości) poziom, do którego się odwołują.

${ }^{42} \mathrm{Z}$ uwagi na nieoficjalny, skierowany do wolontariuszy, charakter owego komunikatu, nie zamieszczam informacji, o którą organizację chodzi. Sam przekaz wydał mi się jednak na tyle w kontekście opisywanego problemu istotny, że zdecydowałam się go zamieścić.

${ }^{43}$ R. Ślusarczyk, Białowieża. Na dzień dobry wieniec nagrobny dla miłośników przyrody, Pracownia.org.pl, http://pracownia.org.pl/aktualnosci,881, (dostęp: 15.10.2012). 
czysto deklaratywny wymiar. Każda z wymienionych grup uważa się za ekspercką w swojej dziedzinie, bez względu na to, czy chodzi o ochronę dzikiej przyrody, czy o sprawowanie władzy. Jednocześnie, wiedzy eksperckiej odmawia się w praktyce mieszkańcom, co sprawia, że nie bierze się pod uwagę ich zdania w procesach decyzyjnych, tylko zdanie to z góry im się narzuca. Przyznany odgórnie pozór suwerenności, jakim jest możliwość decydowania samorządu o powstrzymaniu utworzenia parku narodowego ${ }^{44}$, jest li tylko pozorem, bo ogranicza się do samowładztwa negatywnego, a nie pozytywnego (podobnie, jak w wypadku obiecanych mieszkańcom przez Ministerstwo Środowiska funduszy strukturalnych, które wykorzystane mogły być tylko na określony rodzaj inwestycji).

To odsyła nas z kolei do następnego zaniechania, a mianowicie do braku włączania społeczności lokalnej w procesy decyzyjne. Łatwo jest legitymizować swoje decyzje i działania, kiedy uzasadni się je jako vox populi. Kiedy spojrzymy jednak na praktykę demokracji bezpośredniej w naszym kraju, szybko okaże się, że inkluzyjność dotyczy jedynie tych obszarów, w których nie przeszkadza ona istniejącym planom. Budowa kopalni odkrywkowych, autostrad, ogromnych elektrociepłowni, jest konsultowana tylko o tyle, o ile nie godzi to we wcześniej przyjęte plany i strategie ${ }^{45}$. W tej sytuacji głos dany tubylcom w sprawach, które i tak nie generują żadnych kosztów dla budżetu (a czasem, jak w wypadku parków narodowych, wręcz ich ujmują), przypomina jałmużnę rzuconą biedakom po to, by utrzymać decyzyjny status quo.

Budowie społeczeństwa uczestniczącego i włączaniu obywateli w stanowienie prawa, nie sprzyjają również inicjatywy teoretycznie na to zamierzone, zorganizowane jednak w formie projektów i grantów. Czy można budować proces partycypacji w oparciu o jednoroczny (w najlepszym układzie dwuletni) projekt, którego połowę zasobów i tak pochłania biurokracja?

${ }^{44}$ Zgodnie z Ustawq o ochronie przyrody z 2004 roku samorządy mają obowiązek „uzgadniania” planów tworzenia parków narodowych w Polsce, nie zaś, jak było to wcześniej, wyłącznie ich „opiniowania”. W rezultacie oznacza to, że stanowisko samorządu w tej kwestii jest kluczowe dla podjęcia decyzji. Jeżeli będzie ono negatywne, park narodowy nie może powstać ani poszerzyć swych granic. Ustawa o ochronie przyrody z dnia 16 kwietnia 2004, http://isap.sejm.gov.pl/DetailsServlet?id=WDU20040920880, (dostęp: 15.10.2012).

${ }_{45}$ Przykładów poniechań można by podawać wiele, począwszy od raportów środowiskowych, pisanych metodą „kopiuj-wklej” (zob. Polski program jądrowy pisany na kolanie, Greenpeace 2012, http://www.greenpeace.org/poland/pl/wydarzenia/polska/polski-program-jadrowy/, dostęp: 31.05.2013), a skończywszy na przeznaczaniu środków budżetowych na promocję zaplanowanych inwestycji, zamiast na rzetelną ocenę ich skutków. 
Jak zauważają inicjatorzy kampanii Obywatele Decyduja, budowa społeczeństwa obywatelskiego nie jest sprintem, ale maratonem ${ }^{46}$. Potwierdza to antropologiczna praxis, pokazując, że do zmiany głęboko zakorzenionych przekonań i wartości, potrzeba dziesiątek, a nierzadko setek lat. Nawet najlepiej przygotowany projekt grantowy (nie wspominając już o tych przygotowanych źle) niewiele da, jeżeli brak będzie jego kontynuacji. Tymczasem ciągłość takich inicjatyw zostaje zwykle przerwana wraz z ustaniem finansowania, a głównym efektem takich działań są (poza efektami rzeczowymi) tony papieru zużytego na tworzenie nikomu niepotrzebnych tabelek i zestawień.

Pytanie, czy istnieje inna droga? Jakkolwiek przykłady zaczerpnięte z miejsc odmiennych pod względem geograficznym i kulturowym nigdy nie są do końca przekładalne, tutaj chciałabym wskazać na dwa, odnoszące się nie tyle do konkretnych realiów, co do samej metodyki prowadzenia działań, włączających społeczność lokalną w ochronę danego obszaru.

Pierwszy z nich pochodzi aż z Fidżi i dotyczy tzw. Lokalnie Zarządzanych Obszarów Morskich. Obszary te mają na celu ochronę morskiego ekosystemu przed przełowieniem. Można je zatem potraktować jak swoiste rezerwaty. Co jednak istotne dla nas, zostały one utworzone w oparciu o lokalny system wartości i sposoby gospodarowania, co umożliwiło włączenie w proces ochronny tubylczych grup etnicznych. Jak opisuje Rebecca L. Adamson:

Grupy tubylców z wybrzeża, współpracując z naukowcami, chronią gatunki morskich organizmów, stosując tradycyjną metodę, polegającą na ustanawianiu na części wioskowych łowisk specjalnych obszarów wyłączonych z połowów, tzw. tabu, gdzie zwierzęta mogą odbudowywać swoje populacje. W efekcie od kwietnia 1997 r. do sierpnia 2000 r. liczebność takiego np. mięczaka jadalnego koi koso wzrosła o $1353 \%$ w obrębie tabu i o $523 \%$ w wodach wokół tabu ${ }^{47}$.

Ten prosty, a zarazem wymagający dużej znajomości chronionego obszaru zabieg, sprawił, że udało się pogodzić ochronę przyrody z ochroną wartości kulturowych, stwarzając przestrzeń do ponownego odczytania sensów nadawanych przez człowieka przyrodzie.

${ }^{46}$ Obywatele Decydujq. O co chodzi? http://obywateledecyduja.pl/2012/03/o-co-chodzi/, (dostęp: 31.05.2013).

47 R. L. Adamson, Preserves Biodiversity at Less Cost, University of South Pacific 2007, http://www.firstpeoplesworldwide.org/publish/IndigenousStewardshipPreservesBiodiversi tyatLessCost.pdf, za: T. Nakonieczny, Rola rdzennej ludności w ochronie przyrody, „Dzikie Życie” 2012, nr 11, s. 28. 
Zarzut, że to, co się udało na Fidżi, nie musi się wcale udać w Europie Środkowo-Wschodniej, można z kolei odeprzeć z pomocą innego, pochodzącego z zachodniej Ukrainy, przykładu. Jeszcze kilkanaście lat temu sytuacja położonego tam niewielkiego miasteczka Hrycew, była analogiczna do wielu innych miejsc po przemianach ustrojowych - zastałe struktury i model sprawowania władzy oraz brak woli ze strony ekipy samorządowej, żeby taki stan rzeczy zmienić. Reakcją mieszkańców było zawiązanie Stowarzyszenia Odnowy Hrycewa, które we współpracy ze słowacką organizacją pozarządową ACDI/VOCA zorganizowało regularne badania etnograficzne, dotyczące oczekiwań i planów mieszkańców wsi wobec rozwoju ich miejscowości i regionu. Jak pisze autorka artykułu:

Dzięki tym wywiadom w mieszkańcach zaczęło kiełkować poczucie przynależności do lokalnej społeczności i odpowiedzialności za to, co będzie się z nią działo (...). Był to pierwszy krok do rozpoczęcia partycypacyjnego planowania lokalnego rozwoju ${ }^{48}$.

Następnie zaczęto przystępować do wcielenia pomysłów w życie. Okazało się, że do realizacji wielu z nich nie są potrzebne ogromne fundusze, więc zamiastinwestować w jeden ogromny projekt infrastrukturalny, postawiono na 28 mini-projektów, nie tylko zainicjowanych, ale i realizowanych przez mieszkańców regionu. Krok po kroku realizowano plan odnowy, w którym co ciekawe - zamiast forsować wizję przemysłu ciężkiego, autostrad i innych inwestycji czynionych kosztem przyrody, mieszkańcy zdecydowali się na turystyczno-ekologiczne ukierunkowanie, w zgodzie z duchem zrównoważonego rozwoju. W zgodzie z nim, również dlatego (a może właśnie dlatego), że w połączeniu ze społecznością lokalną i znaczeniami, które nadaje ona przyrodzie oraz swoim działaniom w środowisku naturalnym.

Kto wie - może w gruncie rzeczy, zrównoważony rozwój wcale nie jest rozwojem globalnym? Może jest on wytworem konwencji, umów i komisji międzynarodowych w znacznie mniejszym stopniu niż nam się wydaje? Jeżeli najważniejsza część komunikacji międzyludzkiej rozgrywa się w osobistym kontakcie z drugą osobą - w słuchaniu tonu jej głosu, przyglądaniu się gestom, nieuświadamianym sprawdzaniu jej zapachu, to również nasze kształtowanie więzi z naturą, odbywać się winno w pierwszej mierze w sposób niezapośredniczony przez jakiekolwiek środki przekazu? Tak czy

${ }^{48}$ A. Khalaim, Hrycew, Ukraina. Budowanie zrównoważonej społeczności lokalnej. [w:] Zrównoważony rozwój. Zastosowania, pod red. T. Bergier, J. Kronenberg, , Fundacja Sendzimira, Wrocław 2010, s. 68. 
inaczej, droga ku budowie głębszych relacji między człowiekiem a przyrodą, musi wychodzić od budowy głębokich relacji między ludźmi. Jeżeli zrównoważony rozwój traktować będziemy jako ściśle powiązany z pojęciem demokracji ekologicznej, to punktem wyjścia będzie dla niego to samo, co dla demokracji w ogóle - lud. Lud rozumiany jednak nie jako figura retoryczna, nie jako usprawiedliwienie odgórnie podejmowanych decyzji i rozwiązań, ale jako wspólnota doświadczeń, znaczeń, sposobów wartościowania otaczającego świata. Jeżeli zaś światy swoje wartościujemy odrębnie niż inni, uczmy się wykuwać proces środowiskowy w dialogu, w nieustannym słuchaniu się nawzajem i w obopólnych próbach zrozumienia.

\section{BIBLIOGRAFIA}

- Adamska T., Analiza kosztów i korzyści zwiq̨zanych z wydobyciem gazu łupkowego, [w:] Obywatele kontroluja, pod red. D. Żuchowskiego, Instytut Spraw Obywatelskich, Łódź 2013.

- Adamson R. L., Preserves Biodiversity at Less Cost, University of South Pacific 2007, http://www.firstpeoplesworldwide.org/publish/IndigenousStewardshipPreserves BiodiversityatLessCost.pdf, (dostęp: 31.05.2013).

- Bajko P., Z dawnej Białowieży, Wydawnictwo Hajstra, Otwock-Białowieża 2010.

- Bauman Z., Wieloznaczność nowoczesna, nowoczesność wieloznaczna, tłum. J. Bauman, Wydawnictwo Naukowe PWN, Warszawa 1995.

- Bohdan A., Będziem topić w bagnie. „Dzikie Życie” 2010, nr 6, http://pracownia.org.pl /dzikie-zycie-numery-archiwalne,2253,article,5035, (dostęp: 15.10.2012).

- Fydrych A.,Puszcza Białowieska - „Stop wycince!”, http://serwisy.gazetaprawna.pl/ekologia/artykuly/352235,puszcza_bialowieska_stop_wycince.html, (dostęp: 31.05.2013).

- Geertz C., Opis gęsty: w poszukiwaniu interpretatywnej teorii kultury, [w:] Interpretacja kultur. Wybrane eseje, tłum. M. Piechaczek, Wydawnictwo UJ, Kraków 2005.

- Geertz C., Osoba, czas i zachowanie na Bali, [w:] Interpretacja kultur. Wybrane eseje, tłum. M. Piechaczek, Wydawnictwo UJ, Kraków 2005.

- Gliński P., Konflikt o Puszczę. Raport z badań nad konfliktem społecznym dotyczącym poszerzenia Białowieskiego Parku Narodowego, [w:] Pogranicze. Studia Społeczne, pod red. A. Sadowskiego, Wydawnictwo Uniwersytetu w Białymstoku, Białystok 2002.

- Hall E., Taniec życia, tłum. R. Nowakowski, Muza, Warszawa 1999.

- Hastrup K., Droga do antropologii. O ugruntowywaniu się światów - podstawy empiryczne antropologii, tłum. E. Klekot, [w:] Badanie kultury. Kontynuacje, pod red. M. Kempnego, E. Nowickiej, PWN, Warszawa 2004. 
- Jędrzejewska B., Okołów Cz., Samojlik T., Dziedzictwo zobowiązuje. 600 lat ochrony Puszczy Białowieskiej. Materiały Międzynarodowej Konferencji Naukowej, Białowieża, 11-12 września 2009, Ministerstwo Środowiska, Warszawa 2010.

- Kapuściński R., Imperium, Czytelnik, Warszawa 1993, s. 91-109.

- Keller J., Prawosławie, Iskry, Warszawa 1982.

- Khalaim A., Hrycew, Ukraina. Budowanie zrównoważonej społeczności lokalnej, [w:] Zrównoważony rozwój. Zastosowania, pod red. T. Bergier, J. Kronenberg, , Fundacja Sendzimira, Wrocław 2010.

- Korbel J., Puszcza Białowieska (blog internetowy), 25.08.2011, http://puszcza-bialowieska.blogspot.com/, (dostęp: 15.10.2012).

- Kuijper D., Wajrak A., Puszcza Białowieska: oby tylko człowiek jej nie przeszkadzał, Wyborcza.pl, http://wyborcza.pl/1,75476,10935787,Puszcza_Bialowieska__oby_tylko _czlowiek_jej_nie_przeszkadzal.html, (dostęp: 15.10.2012).

- Marcus G., Użyteczność kategorii uczestnictwa w zmieniających się kontekstach antropologicznych badań terenowych, [w:] Clifford Geertz - Lokalna lektura, pod red. D. Wolskiej, M. Brockiego, Wydawnictwo UJ, Kraków 2002.

- Nakonieczny T., Rola rdzennej ludności w ochronie przyrody, „Dzikie Życie” 2012, nr 11, s. 28.

- Obywatele Decydują. O co chodzi? http://obywateledecyduja.pl/2012/03/o-co-chodzi/, (dostęp: 31.05.2013).

- Polski program jądrowy pisany na kolanie, Greenpeace 2012, http://www.greenpeace. org/poland/pl/wydarzenia/polska/polski-program-jadrowy/, (dostęp: 31.05.2013).

- Reportaż o Puszczy Białowieskiej, Telewizja ONT, 2011, http://www.youtube.com /watch?v=0ZJ0Lyq_OMk, (dostęp: 15.10.2012).

- Sahlins M., Struktura a historia, [w:] Wyspy historii, tłum. I. Kołbon, Wydawnictwo UJ, Kraków 2006.

- Schmidt P., „Centralność” $i$ „pograniczność”. Dwa modele tożsamości, „Lud”, t. 86, 2002.

- Ślusarczyk R., Białowieża. Na dzień dobry wieniec nagrobny dla miłośników przyrody, Pracownia.org.pl, http://pracownia.org.pl/aktualnosci,881, (dostęp: 15.10.2012).

- Ustawa o ochronie przyrody z dnia 16 kwietnia 2004, http://isap.sejm.gov.pl/Details Servlet?id=WDU20040920880, (dostęp: 15.10.2012).

- Weber M., Obiektywność poznania w naukach społecznych, tłum. M. Skwieciński, [w:] Problemy socjologii wiedzy, pod red. A. Chmieleckiego PWN, Warszawa 1985.

- Wesołowski T., Bożek G., Puszcza jest naszą rafą koralowa - z prof. Tomaszem Wesołowskim rozmawia Grzegorz Bożek. „Dzikie Życie” 2005-2006, nr 12-1, http://pracownia. org.pl/dzikie-zycie-numery-archiwalne,2137,article,2759, (dostęp: 15.10.2012). 
FROGS, PEOPLE AND THE WORLD OF MEANINGS - Problems of Sustainable development in Poland

In the article author discusses problem of connection between environmental policy, social and cultural life in Poland. When talking about sustainable development, we should keep in mind not only statistic data related to local communities but also meanings that they put to natural environment. Do authorities take citizens opinion into consideration at all? Do ecological organizations see correlation between protection of nature and protection of cultural values? Is creating such a link possible at all? These and many other questions are considered according to field research conducted by author in Białowieża.

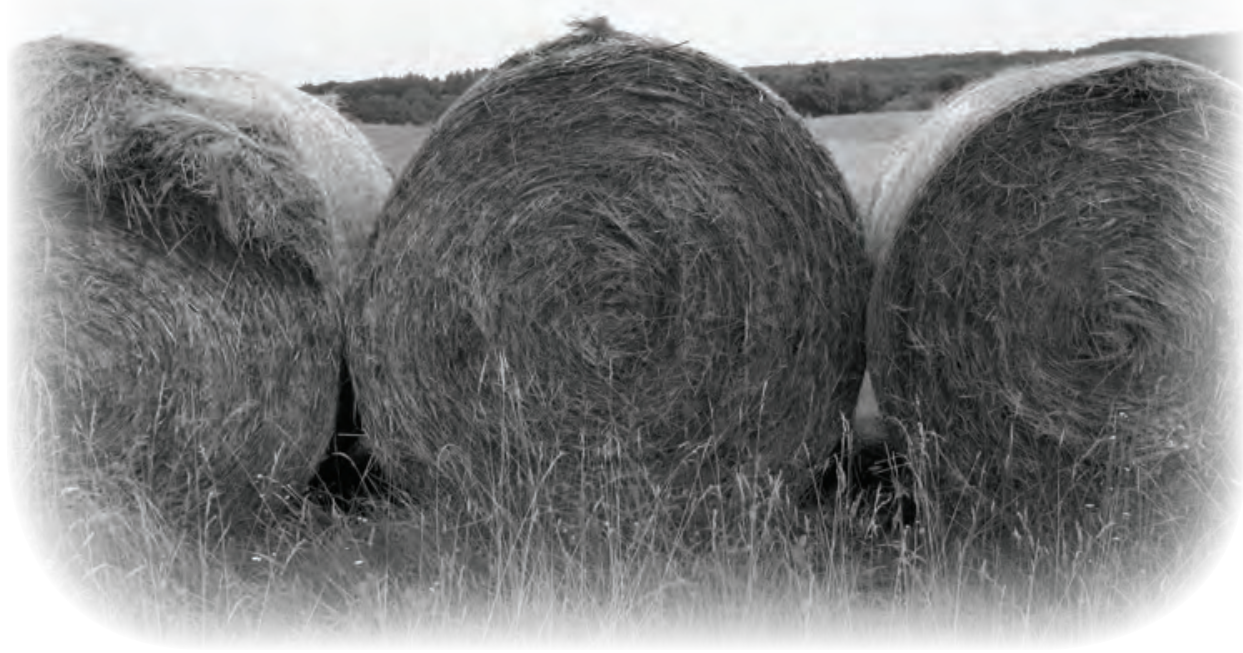

